\title{
IDENTIFIKASI KARAKTERISTIK PERMUKIMAN KUMUH DI SEKITAR TAMAN MACCINI SOMBALA KOTA MAKASSAR
}

\author{
Irma Rahayu ${ }^{1}$, Wahyuni Jaharuddin ${ }^{2}$ \\ ${ }^{1}$ Jurusan Teknik Arsitektur, \\ Fakultas Sains dan Teknologi UIN Alauddin Makassar \\ Jl. Sultan Alauddin No. 63, Kabupaten Gowa, Sulawesi Selatan. 92113 \\ ${ }^{2}$ Jurusan Teknik Arsitektur PPs Universitas Hasanuddin \\ Jl. Perintis Kemerdekaan KM.10, Kota Makassar, Sulawesi Selatan. 90245 \\ E-mail: irmamgee@yahoo.go.id,ywah34@yahoo.com
}

\begin{abstract}
Slum area is an area with a high population density in a city that is generally inhabited by poor people. Slums can be found in various major cities in the world. Slums are generally associated with high levels of poverty and unemployment. The rapid development of urban settlements is caused by population growth and urbanization which has resulted in slums. One of the slums in Makassar is located on Jl. Maccini Kelurahan Maccini Sombala, Makassar City. Residents who live in groups and build houses without thinking about space for housing support facilities. The houses in this settlement are semi-permanent and not permanent. Most are in the form of houses on stilts with very limited infrastructure, such as lack of road facilities, environmental drainage, clean water, waste water, and solid waste. The level of income of the population is very low where most residents work as fishermen, small traders, and artisans. The purpose of this study was to identify the characteristics of slums in Maccini Sombala Village. The benefits of this research are input for the Regional Government and the local community to formulate slum reduction policies, develop slum settlement structuring strategies by reviewing current conditions and alternative structuring in the future. From the results of primary and secondary data acquisition, the author uses a qualitative analysis method that is describing the data which is then followed by interpretation and conclusions. Presentation of data descriptively is by explaining, describing, and solving problems that are closely related to this research. The results of identification of residential buildings, the technical requirements of the building is known that $81 \%$ of buildings are not in accordance with the requirements in terms of safety, comfort, and health and $19 \%$ of livable buildings (according to building standards).
\end{abstract}

Keywords: characteristics, identification, Makassar City, settlement

\section{PENDAHULUAN}

$\mathrm{P}$ esatnya pertumbuhan penduduk yang diikuti dengan semakin meningkatnya kebutuhan akan ruang bermukim menyebabkan pembangunan rumah tipe modern dan tempat-tempat untuk usaha oleh masyarakat sendiri terus bertambah. Pembangunan yang tidak disertai dengan pengaturan dan pengendalian yang baik menjadikan lingkungan kampung tersebut kumuh, tidak teratur, tidak nyaman dan tidak sehat. 
Permukiman kumuh adalah permukiman yang tidak layak huni karena tidak teratur tata letak bangunan, tingkat kepadatan tinggi, dan kualitas bangunan serta sarana dan prasarana tidak memenuhi syarat, sedangkan perumahan kumuh adalah perumahan yang mengalami penurunan kualitas fungsi sebagai tempat hunian (Undang-Undang Republik Indonesia Nomor 1 Tahun2011).

Berdasarkan Surat Keputusan Walikota Makasar No 050. 05/1341/ Kep/05/2014 tentang Penetapan Lokasi Kumuh Kota Makassar Tahun Anggaran 2014, bahwa telah tercacat 103 kelurahan yang termasuk wilayah kumuh dari 143 kelurahan. 3 Sebanyak 432.115 jiwa atau 131.299 kepala keluarga (kk) dari total penduduk kota Makassar yang menetap dalam kawasan pemukiman kumuh.

Luasan kawasan permukiman kumuh di Kota Makassar diklasifikasikan ke dalam kategori kumuh berat, kumuh sedang dan kumuh ringan. Kumuh berat terdapat di 36 kelurahan, kategori kumuh sedang di 49 kelurahan dan 17 kelurahan masuk kategori kumuh ringan. 4 Kecamatan Tamalate merupakan salah satu dari 14 Kecamatan di Kota Makassar yang terdiri dari 10 Kelurahan yaitu Kelurahan Barombong, Tanjung Merdeka, Maccini Sombala, Balang Baru, Jongaya, Bungaya, Pa'baengbaeng, Mannuruki, Parang Tambung dan Mangasa.

Adapun kelurahan yang termasuk wilayah kumuh berat yang ada di Kecamatan Tamalate yaitu kelurahan Mangasa, Parang Tambung, Tanjung Merdeka, Barombong dan Maccini Sombala. Salah satu permukiman kumuh yang menjadi lokasi penelitian ini, terletak di Kota Makassar adalah Kelurahan Maccini Sombala. Permukiman ini memiliki luas sekitar 2,04 $\mathrm{km}^{2}$ dan terdiri dari $72 \mathrm{RT}$ dan 9 RW dengan jumlah penduduk laki-laki 11.585 dan perempuan 10.999 .

Kawasan permukiman di sekitar Taman Maccini Sombala ini merupakan area permukiman kumuh yang sangat penting diperhatikan oleh pemerintah setempat. Kondisi bangunan yang tidak teratur, tempat pembuangan sampah yang tidak tersedia, saluran yang kurang memadai dan tidak teratur membuat kawasan di Jl. Maccini terlihat kumuh dan semrawut.

Kawasan kumuh adalah kawasan di mana rumah dan kondisi hunian masyarakat di kawasan tersebut sangat buruk. Rumah maupun sarana dan prasarana yang ada tidak sesuai dengan standar yang berlaku, baik standar kebutuhan, kepadatan bangunan, persyaratan rumah sehat, kebutuhan sarana air bersih, sanitasi maupun persyaratan kelengkapan prasarana jalan, ruang terbuka, serta kelengkapan fasilitas sosial lainnya (Kurniasih, 2007). Permukiman kumuh berdasarkan Undang-Undang Nomor 1 Tahun 2011 Pasal 1 ayat (13) adalah permukiman yang tidak layak huni karena ketidakteraturan bangunan, tingkat kepadatan bangunan yang tinggi, dan kualitas bangunan serta sarana dan prasarana yang tidak memenuhi syarat.

Menurut Sinulingga (2005) ciri kampung/pemukiman kumuh terdiri dari:

1. Penduduk sangat padat antara 250-400 jiwa/ha. Pendapat para ahli perkotaan (MMUDP,90) menyatakan bahwa apabila kepadatan suatu kawasan telah mencapai 80 jiwa/ha maka timbul masalah akibat kepadatan ini, antara perumahan yang dibangun tidak mungkin lagi memiliki persyaratan fisiologis, psikologis dan perlindungan terhadap penyakit.

2. Jalan-jalan sempit tidak dapat dilalui oleh kendaraan roda empat, karena sempitnya, kadang-kadang jalan ini sudah tersembunyi di balik atap-atap rumah yang sudah bersinggungan satu sama lain.

3. Fasilitas drainase sangat tidak memadai dan malahan biasa terdapat jalan-jalan tanpa drainase, sehingga apabila hujan kawasan ini dengan mudah akan tergenang oleh air. 
4. Fasilitas pembuangan air kotor/tinja sangat minim sekali. Ada di antaranya yang langsung membuang tinjanya ke saluran yang dekat dengan rumah, ataupun ada juga yang membuangnya ke sungai yang terdekat.

5. Fasilitas penyediaan air bersih sangat minim, memanfaatkan air sumur dangkal, air hujan atau membeli secara kalengan.

UN-HABITAT (2007) mendefinisikan rumah tangga dalam permukiman kumuh (slum household) adalah kelompok individu yang tinggal di bawah satu atap di daerah perkotaan yang tidak mempunyai salah satu dari indikator berikut:

1. Rumah yang kokoh, yang dapat melindungi penghuninya dari kondisi cuaca yang buruk;

2. Ruang huni yang cukup, yang berarti tidak lebih dari tiga orang menghuni 1 ruang bersama;

3. Kepastian atau rasa aman bermukim (secure tenure), yang dapat melindungi penghuninya dari penggusuranpaksa.

Beberapa kriteria permukiman kumuh menurut UN-HABITAT (2008) adalah rumah tangga yang memiliki salah satu dari kriteria berikut:

1. Tidak memadainya ketersediaan air minum yang aman (inadequate access to safe water);

2. Tidak memadainya ketersediaan sanitasi beserta infrastrukturnya (inadequate access to sanitation and other infrastructure);

3. Kualitas bangunan yang rendah (poor structural of housing);

4. Ruang huni yang padat (overcrowding);

5. Status hunian yang tidak aman (insecure residential status).

Maka jika rumah tangga memiliki salah satu dari kriteria di atas, sudah dikategorikan sebagai rumah kumuh (slum dwelling) Ketentuan tersebut hanya akan menampilkan dua jenis data yaitu kumuh dan tidak kumuh.

Model penataan permukiman kumuh mempunyai persamaan dan perbedaan. Untuk menciptakan model yang memiliki persamaan dan perbedaan maka model tersebut dikelompokkan seperti yang terdapat pada Tabel 1.

Tabel 1. Pengelompokan Model Penataan Permukiman Kumuh

\begin{tabular}{lll}
\hline Pilihan Tempat Tinggal & Model Penataan & Orientasi Model \\
\hline $\begin{array}{l}\text { Tetap di lokasi } \\
\text { perumahan }\end{array}$ & Land Sharing & $\begin{array}{l}\text { Perbaikan lahan dan lingkungan } \\
\text { Permukiman }\end{array}$ \\
\cline { 2 - 3 } $\begin{array}{l}\text { Land } \\
\text { Consolidation }\end{array}$ & $\begin{array}{l}\text { Perbaikan lahan dan lingkungan } \\
\text { Permukiman }\end{array}$ \\
\hline Slum Upgrading & $\begin{array}{l}\text { Perbaikan sosial penduduk, lahan dan } \\
\text { perumahan, } \\
\text { sarana dan prasarana }\end{array}$ \\
& $\begin{array}{l}\text { Lebih berorientasi kepada perbaikan } \\
\text { lahan untuk } \\
\text { kepentingan komersil }\end{array}$ \\
\hline $\begin{array}{l}\text { Property } \\
\text { Development }\end{array}$ & $\begin{array}{l}\text { Perbaikan permukiman melalui } \\
\text { swadaya }\end{array}$ \\
& $\begin{array}{l}\text { Community } \\
\text { Based } \\
\text { Development }\end{array}$ & $\begin{array}{l}\text { Pengendalian lahan melalui peraturan } \\
\text { zona }\end{array}$ \\
\hline $\begin{array}{l}\text { Guide Land } \\
\text { Development }\end{array}$ & Perbaikan fisik bangunan \\
& $\begin{array}{l}\text { On-Site } \\
\text { Reconstruction }\end{array}$ \\
\hline
\end{tabular}




\begin{tabular}{lll}
\hline & $\begin{array}{l}\text { On-Site } \\
\text { Reblocking }\end{array}$ & Perbaikan lahan dan permukiman \\
\cline { 2 - 3 } & $\begin{array}{l}\text { On-Site } \\
\text { Upgrading }\end{array}$ & $\begin{array}{l}\text { Perbaikan fisik dan pelayanan sosial } \\
\text { masyarakat }\end{array}$ \\
\cline { 2 - 3 } & Pemugaran & Perbaikan fisik bangunan \\
\cline { 2 - 3 } & Peremajaan & Perbaikan kualitas lingkungan \\
\hline $\begin{array}{l}\text { Pesettlement } \\
\text { lokasi Perumahan }\end{array}$ & $\begin{array}{l}\text { Pemindahan lokasi perumahan } \\
\text { penduduk }\end{array}$ \\
\cline { 2 - 3 } & Relocation & $\begin{array}{l}\text { Pemindahan lokasi perumahan } \\
\text { penduduk }\end{array}$ \\
\hline Sumber: Undang-Undang Republik Indonesia Nomor 1 Tahun 2011; & Wekesa et al., 2011; Sulestianson, 2014
\end{tabular}

\section{METODE PENELITIAN}

Lokasi penelitian terletak di Jl. Maccini Kelurahan Maccini Sombala Kota Makassar tepatnya di sekitar Taman Maccini Sombala. Dari hasil perolehan data primer dan sekunder, penulis menggunakan metode analisis kualitatif yaitu mendeskriptifkan data tersebut yang selanjutnya diikuti dengan penafsiran dan kesimpulan. Penyajian data secara deskriptif yaitu dengan cara menjelaskan, menggambarkan dan memecahkan permasalahan yang erat kaitannya dengan penelitian ini. Wawancara dilakukan pada instansi pemerintahan terkait. Batas penelitian ini hanya mengidentifikasi karakteristik permukiman kumuh untuk menghasilkan model penataan permukiman di sekitar Taman Maccini Sombala, Jl. Maccini Kelurahan Maccini Sombala Kota Makassar.

\section{HASIL DAN PEMBAHASAN}

\section{A. Gambaran Umum}

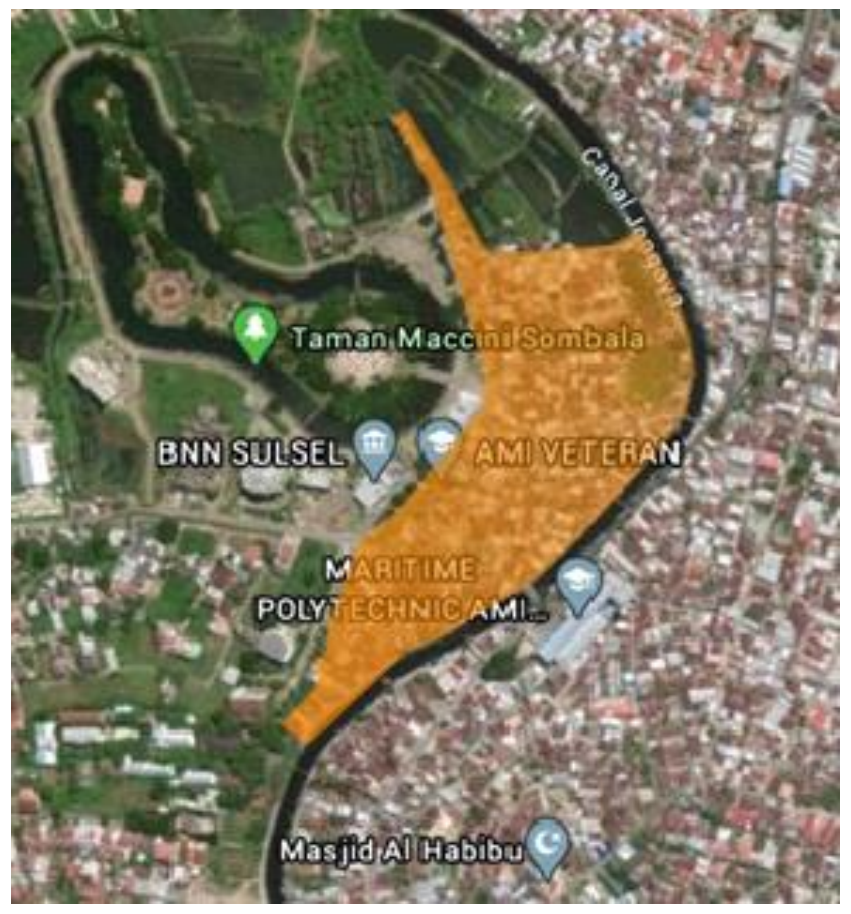

Gambar 1. Lokasi penelitian (Sumber: Hasil observasi, Juni2020) 
Kelurahan Maccini Sombala dulunya disebut Kampung Gusung Jonga yang dihuni oleh para penggarap dan pemilik lahan yang sebagian besar tanah milik keturunan rajaraja Gowa. Disebut Gusung Jonga karena di daerah tersebut banyak terdapat rusa (jonga), baik rusa liar maupun rusa peliharaan raja yang dilepas di area tersebut. Kemudian nama Kampung Gusung Jonga berubah menjadi Maccini Sombala karena letak geografisnya yang berada pada pesisir pantai sehingga ketika orang berdiri di pinggir pantai maka orang dapat melihat ujung layar perahu yang akan berlabuh di daerah pantai Maccini Sombala. Kawasan kumuh Kelurahan Maccini Sombala terletak di sekitar Taman Maccini Sombala tepatnya di Jl. Maccini, Kota Makassar.

\section{B. Identifikasi Kondisi Bangunan Hunian}

Kepadatan bangunan menunjukkan banyaknya bangunan (unit) dalam satu luas lahan tertentu (bangunan/ha). Tingkat kepadatan bangunan di kawasan sekitar Taman Maccini Sombala masih termasuk tinggi dengan penjelasan sebagaimana ditunjukkan pada Tabel 2.

Tabel 2. Tingkat Kepadatan Bangunan di Jl. Maccini Kelurahan Maccini Sombala

\begin{tabular}{|c|c|c|c|c|c|c|c|c|}
\hline $\begin{array}{l}\text { Nama } \\
\text { Lokasi }\end{array}$ & $\begin{array}{l}\text { Luas } \\
\text { (Ha) }\end{array}$ & $\begin{array}{c}\mathbf{R T} / \mathbf{R} \\
\mathbf{W}\end{array}$ & Kel. & Kec. & Lintang & Bujur & $\begin{array}{c}\text { Jumlah } \\
\text { RT }\end{array}$ & $\begin{array}{c}\text { Legalitas } \\
\text { Lahan }\end{array}$ \\
\hline $\begin{array}{l}\text { Jl. } \\
\text { Maccin } \\
\text { i }\end{array}$ & 30.27 & $\begin{array}{c}\text { RW } \\
03 / 05 / \\
06 / \\
07\end{array}$ & $\begin{array}{l}\text { Maccini } \\
\text { Sombala }\end{array}$ & $\begin{array}{l}\text { Tama } \\
\text { late }\end{array}$ & $\begin{array}{c}\text { 5'10"4.49 } \\
\text { LS } \\
5 \text { '10"29.99 } \\
\text { LS }\end{array}$ & $\begin{array}{c}\text { 119’26”19.15 } \\
\text { BT } \\
119 ’ 24 ” 14.3 \\
\text { BT }\end{array}$ & 340 & $\begin{array}{c}85 \% \text { milik } \\
\text { pribadi } \\
\text { dan } 15 \% \\
\text { milik } \\
\text { pemerintah }\end{array}$ \\
\hline
\end{tabular}

Sumber: Hasil observasi dan data RP2KPKP, 2016

Kriteria persyaratan teknis bangunan dapat disimpulkan bahwa rumah yang tidak sesuai persyaratan teknis bangunan hunian merupakan rumah yang tidak layak huni sedangkan rumah yang sesuai dengan standar teknis bangunan hunian merupakan rumah layak huni. Untuk lebih jelas dapat dilihat pada Tabel 3.

Tabel 3. Jumlah Bangunan Hunian Berdasarkan Kesesuaian Syarat Teknis Permukiman Kumuh Kawasan sekitar Taman Maccini Sombala

\begin{tabular}{lcc}
\hline \multicolumn{1}{c}{ Identifikasi Bangunan } & $\begin{array}{c}\text { Jumlah } \\
(\text { unit })\end{array}$ & Persentase (\%) \\
\hline $\begin{array}{l}\text { Bangunan layak huni (sesuai standar } \\
\text { bangunan) }\end{array}$ & 64 & 19 \\
\hline $\begin{array}{l}\text { Bangunan tidak layak huni (tidak sesuai } \\
\text { standar bangunan) }\end{array}$ & 276 & 81 \\
\hline Total & 340 & 100 \\
\hline Sumber: Hasil observasi, 20 Mei- 4 Juni 2020
\end{tabular}

Berdasarkan identifikasi bangunan hunian, syarat teknis bangunan diketahui bahwa $81 \%$ bangunan tidak sesuai persyaratan segi keselamatan, kenyamanan, dan kesehatan. 


\section{Identifikasi Kondisi Jalan Lingkungan}

Berdasarkan hasil analisis kualitas jalan di Jl. Maccini Kelurahan Maccini Sombala, terdapat beberapa lorong kecil yang sangat padat dikelilingi oleh bangunan. Pengaturan bangunan yang tidak teratur membuat jalan tidak efektif untuk dilalui oleh pengguna jalan.
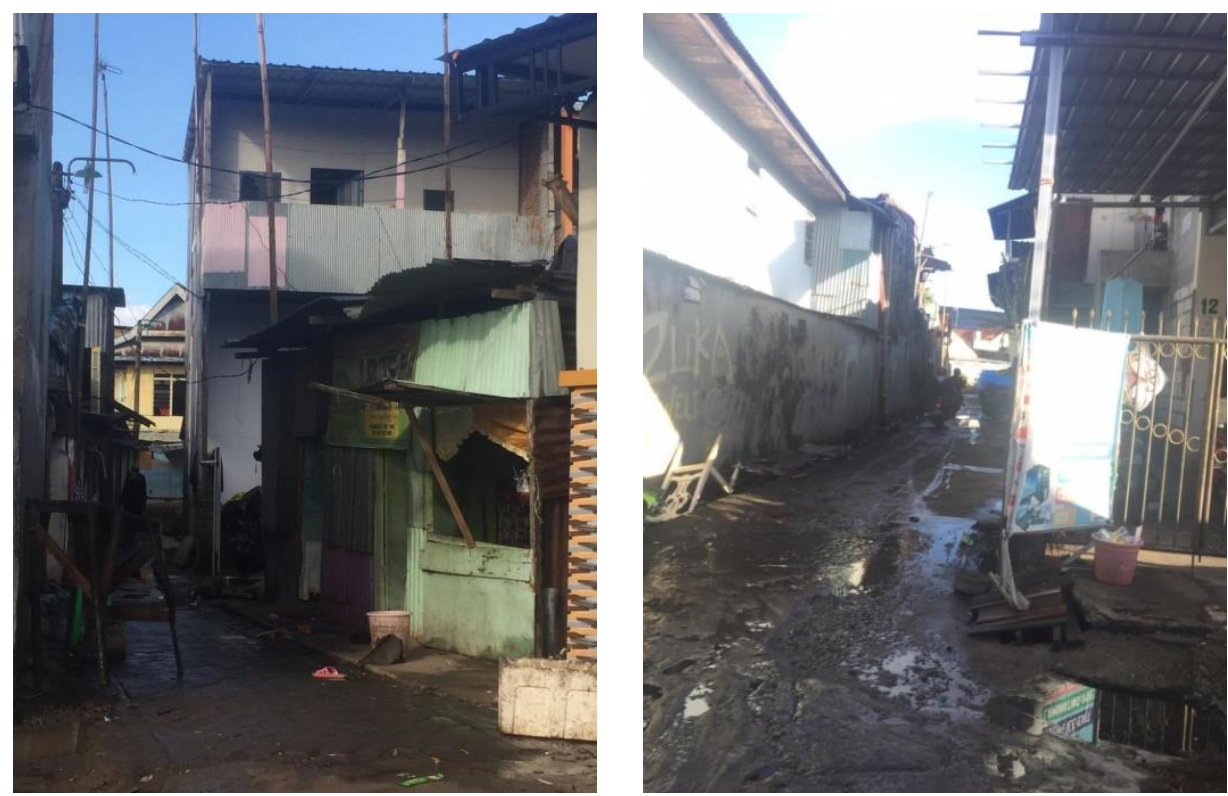

Gambar 2 Kondisi jalan lingkungan

(Sumber: Hasil survey lapangan, Juni 2020)

\section{Identifikasi Kondisi Drainase Lingkungan}

Permukiman kumuh di sekitar Taman Maccini Sombala keseluruhan merupakan jalan setapak dan jalan lingkungan permukiman kurang memiliki prasarana drainase lingkungan. Air hujan dan air limbah langsung meresap ke tanah dan dialirkan ke saluran yang kecil tertutupi oleh plat jalan rumah warga, sehingga sering menimbulkan genangan seperti yang terlihat pada Gambar 3 .

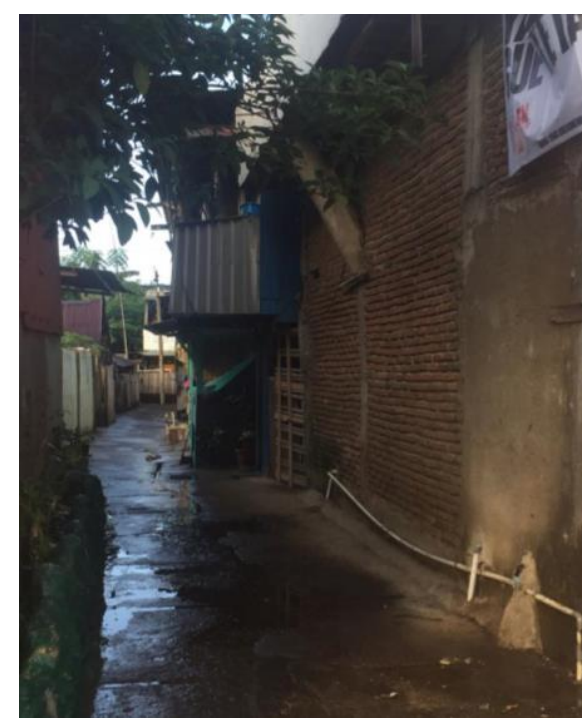

Gambar 3. Kondisi drainase lingkungan (Sumber: Hasil survey lapangan, Juni 2020) 


\section{E. Identifikasi Kondisi Pengelolaan Persampahan}

Tidak tersedianya bak sampah maupun TPS atau TPST. Tidak ada pemeliharaan khusus terhadap sarana dan prasarana persampahan yang ada di sekitar Taman Maccini Sombala. Berdasarkan hasil observasi bahwa penyediaan sarana dan prasarana persampahan di permukiman kumuh Kelurahan Maccini Sombala diketahui belum memiliki sarana dan prasarana persampahan yang baik dan sesuai kriteria kelayakan, hal tersebut dapat dilihat pada Gambar 4.

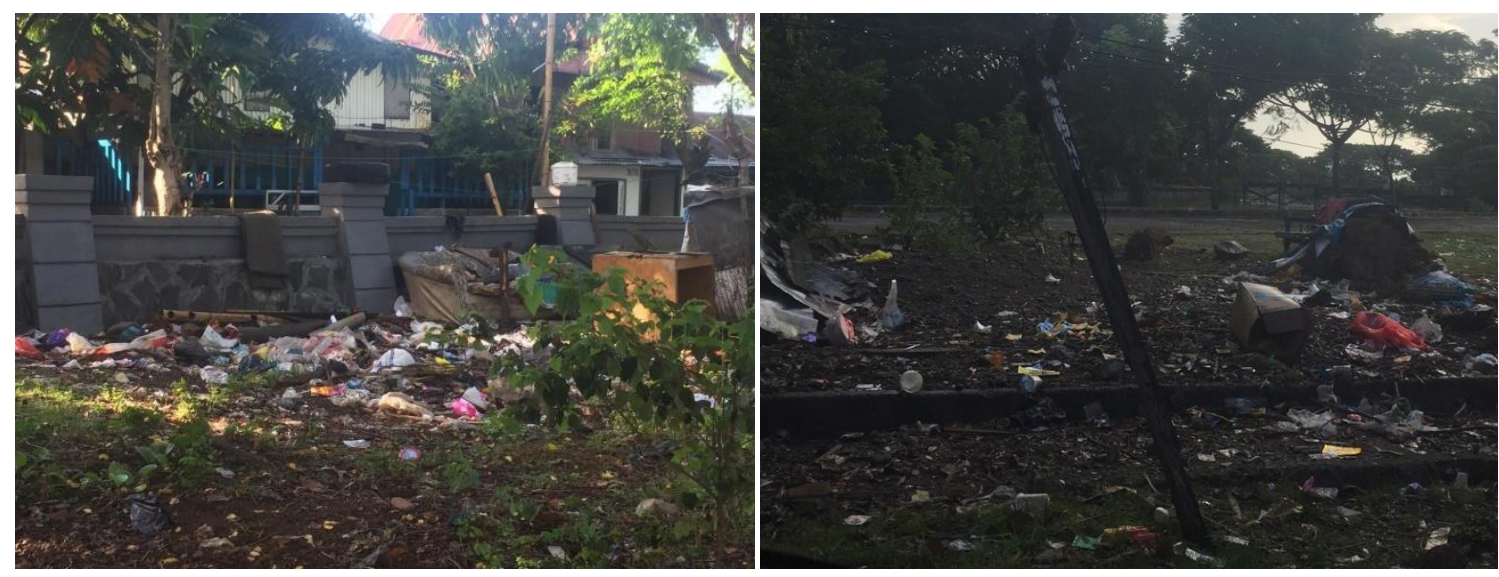

Gambar 4. Kondisi pengolahan sampah

(Sumber: Hasil survey lapangan, Juni 2020)

\section{F. Identifikasi Kondisi Pengamanan Kebakaran}

Kawasan kumuh Kelurahan Maccini Sombala terletak di sekitar Taman Maccini Sombala tepatnya di Jl. Maccini, tidak memiliki prasarana proteksi kebakaran yang baik, kondisi permukiman padat huni dan letak perumahan sangat dekat dan kondisi jalan tidak dapat dilalui mobil pemadam.

Sarana proteksi kebakaran terkait kesediaan Alat Pemadam Api Ringan (APAR), mobil pompa, pompa dorong, pompa motor maupun mobil tangga. Permukiman kumuh di lokasi tersebut $100 \%$ tidak memiliki sarana proteksi kebakaran. Sarana pendukung operasi pemadaman kebakaran dari pemerintah. Kesadaran masyarakat akan bahaya kebakaran juga masih sangat rendah, Sistem penanggulangan kebakaran salah satu prioritas yang wajib dimiliki masyarakat di permukiman kumuh.

\section{KESIMPULAN}

Dari hasil analisis menunjukkan bahwa kawasan di sekitar Taman Maccini Sombala, Jl. Maccini, Kelurahan Maccini Sombala, Kota Makassar merupakan permukiman kumuh dengan kategori kumuh berat. Tingkat kekumuhan disebabkan oleh faktor penataan bangunan yang tidak teratur, kondisi jalan yang tidak efektif, saluran drainase yang kurang memadai, penyediaan TPS yang tidak ada, dan masyarakat yang kurang rasa sadar terhadap lingkungannya.

\section{DAFTAR PUSTAKA}

Kurniasih, S. (2007). Usaha Perbaikan Permukiman Kumuh di Pertukangan Utara Jakarta Selatan. Jurnal. Fakultas Teknik Universitas Budi Luhur. 
Peraturan Menteri Pekerjaan Umum dan Perumahan Rakyat Republik Indonesia Nomor 14/PRT/M/2018 tentang Pencegahan dan Peningkatan Kualitas Terhadap Perumahan Kumuh dan Permukiman Kumuh.

Putro, Jawas Dwijo. (2011). Penataan Kawasan Kumuh Pinggiran Sungai di Kecamatan Sungai Raya. Jurnal Teknik Sipil Untan, 11(1).

Sinulingga, B.D. (2005). Pembangunan Kota. Tinjauan Regional dan Lokal. Jakarta: Pustaka Sinar Harapan.

Surat Keputusan Walikota Makasar No 050. 05/1341/ Kep/05/2014 Tentang Penetapan Lokasi Kumuh Kota Makassar Tahun Anggaran 2014.

Undang-Undang Republik Indonesia Nomor 1 Tahun 2011 tentang Perumahan dan Kawasan Permukiman. LembaranNegara Republik Indonesia Tahun 2011 Nomor 5188. Jakarta: Sekretariat Negara. (Akses via: http://ehousing.perumahan.pu.go.id.).

UN-HABITAT. (2007). Inclusive and Sustainable Urban Planning: A Guide for Municipalities. Volume 1: An Introduction to Urban Strategic Planning. Nairobi, Kenya: UNHABITAT Publications.

UN-HABITAT. (2008). Panduan Ringkas untuk Pembuat Kebijakan 2, Perumahan untuk MBR: Memberi Tempat yang Layak Bagi Kaum Miskin Kota, Edisi Indonesia. Naerobi: United Nations. 